\title{
Eva Hættner Aurelius \& Thomas Götselius (red.): Genreteori. Lund: Studentlitteratur, 1997
}

Genrebegrebet har efterhånden fået en meget central placering inden for såvel litteratur- som sprogforskning. "Det ligger i språkets själva natur att röra sig inom abstraktionen och det 'generiska'. Det individuella kan inte existera $i$ språket, och vår beskrivning av det specifika i en text blir automatisk en beskrivning av en genre, vars särskilda egenskap är att verket ifråga är genrens första och enda exemplar", som Tzvetan Todorov skriver i sin text om de litterære genrer, medtaget i en nyudkommen antologi fra Studentlitteratur. Det faktum, at tekster er udtryk for noget alment, noget overgribende, og at dette noget er centralt i såvel produktionen som interpretationen af tekster, er formodentlig en af de væsentligste grunde til at genrebegrebet har fået den betydning, det har i dag. Samtidig har man fået øjnene op for, at genrebegrebet sætter sig igennem i alle tekster, ikke kun skønlitterære eller "fine" tekster, men også i hverdagens brugstekster.

Nærværende antologi samler 11 tekster fra perioden 1930 til 1983 med fokus på diskussionen af litterære genrer. Her findes tekster af André Jolles, Karl Viëtor, Hans Robert Jauss, Todorov, Klaus W. Hempfer, Robert Scholes, Gérard Genette, Michail Bachtin, Wolf Dieter Stempel, Alaistair Fowler og Jean-Marie Schaeffer. Selv om fokus er på det litterære, kan også sprogforskere med udbytte læse flere af bidragene; dels beskæftiger en tekst som Bachtins "Frågan om talgenrer" sig med et sprogligt emne, dels handler en del af teksterne om de teoretiske problemstillinger ved genreinddelinger og -definitioner; problemer, som også sprogforskningen kæmper med. 